\title{
UNIVERSAL THEORY OF ATHEROSCLEROSIS PATHOGENESIS
}

Shupyk National Medical Academy of Postgraduate Education <liliyaivanitska@gmail.com>

The paper shows that atherosclerosis results from disturbed cholesterol homeostasis in the body, the development of systemic stromal-vascular lipid-protein dystrophy (or lipidosis, or cholesterolosis) complicated by extracellular focal lipid deposits with a predominant cholesterol in the interstitial tissue of the inner arterial and aortic layer. These deposits are foreign to this body tissue. They induce the development of chronic productive granulomatous inflammation in it - granulomatosis around endogenous foreign bodies. Cholesterol deposition is promoted by a positive cholesterol balance in the body; increased permeability of the endothelium in hemodynamically vulnerable parts of the arteries, where blood components, including LP, infiltrate their wall; a lack of hydrolytic enzymes in the cell lysosomes that could destroy the steroid nucleus of the cholesterol molecule. Being essential for each specific organism (for building membranes, the formation of bile acids, the synthesis of steroid hormones, vitamin $\left.D_{3}\right)$, cholesterol, if exceeded, can increase the probability of developing atherosclerosis. Genetic mechanisms are implicated in the disturbed lipid protein metabolism in the human body. Hyperlipoproteinemias (HLPS) are known to be the most common metabolic disorders. The dystrophy under consideration results from primary HLP types IIa, IIb, III, IV, V, as well as secondary HLPs in patients with various medical conditions associated with an increase in blood LDL and / or VLDL and/or a decrease in HDL. A reduced cholesterol efflux from peripheral tissues due to a decreased HDL content and the development of lipidosis are seen in diabetes, obesity, physical inactivity, stress, puberty, menopause, hypertriglyceridemia, cigarette smoking, uremia, treatment with anabolic steroids, beta-adrenergic blocking agents, gestagens, and the use of contraceptives. The most pronounced manifestations of dystrophy are characteristic of HLP types IIA, IIb, III, but its moderate development complicated by atherosclerosis also occurs in types $I V$ and $V$, which are accompanied by increased blood VLDL. Mutations of LDL receptor genes, apoprotein genes lead to the development of stromal vascular dystrophy and atherosclerosis. A number of rare genetic disorders of sterol metabolism accompany impaired metabolism of cholesterol and its esters: hepatic lipase deficiency (with accumulation of VLDL and IDLs); a deficiency in lysosomal hydrolase of cholesterol esters with impaired LDL metabolism (Wolman disease); cholesterol ester accumulation disease; cerebrotendinous xanthomatosis; cerebral cholesterolosis; Toichlander and Hand Schüler Christian syndromes. The main factor contributing to the development of inflammation in the inner vascular wall of arteries and aorta in atherosclerosis is the cyclic hydrocarbonic structure of cholesterol, which cannot be cleaved in the lysosomes of MPs. The leading role of the cyclic hydrocarbonic structure of cholesterol, which is insoluble and indestructible by MPs, in the induction of atherosclerosis-related inflammation is confirmed by the fact of the atherogenic action of cholesterol derivatives having its structure. An important factor in inflammatory morphogenesis is the lipoprotein dyscolloidosis occurring in the arterial intima and the physical and chemical metamorphosis of cholesterol. A colloidal solution, solid crystals of free cholesterol and liquid crystals of cholesterol esters have a pronounced phlogogenic and sclerogenic effect on the interstitial tissue of the arterial intima.

Key words: adipose dystrophy; cholesterol; atherosclerosis; granulomatosis around endogenous foreign bodies.

Despite the fact that the stages of atherogenesis have been largely studied, a holistic vision-based concept of atherosclerosis pathogenesis has not been documented yet. In recent years, there has been a return to the inflammatory concept of the 
disease, but the cause and essence of the inflammatory process in the arterial intima has remained unclear so far.

In our point of view, in order to arrive at a holistic vision of atherosclerosis pathogenesis, a number of facts should be taken into account. To begin with, the genetically determined nature of cholesterol metabolism in the human body is based on the balance between its intake + synthesis and excretion [8]. In the steady state, the total amount of cholesterol entering the intestine with food and cholesterol synthesized in tissues is equal to the total amount of cholesterol and bile acids excreted. The balance, which is represented as the difference between the intake and excretion of cholesterol in the body, can be zero, positive or negative. If the balance between the intake of cholesterol from food and its synthesis in the body, on the one hand, and the excretion of bile acids and cholesterol, on the other hand, is compromised, then the concentration of cholesterol in the tissues and blood changes [8]. With an increase in the concentration of cholesterol in the blood, the likelihood of atherosclerosis and cholelithiasis rises. The positive balance of cholesterol is accompanied by its infiltration into the connective tissue of the arterial intima and stroma of various organs, and the occurrence of stromal vascular adipose dystrophy $[2,16]$. Given the fact that cholesterol is transported and enters the cells as part of lipoprotein particles (LP), this dystrophy is also called lipid-protein or cholesterolosis [7]. Pathologists define stromal vascular adipose dystrophies (lipidoses) which occur when the metabolism of neutral fats and cholesterol and its esters is impaired [16]. Compromised metabolism of cholesterol and its esters results in atherosclerosis with its main manifestation - the deposition of cholesterol in the walls of large and mediumsized arteries of elastic and muscular-elastic types. Lipid spots and strips are initial atherosclerotic changes. Later on, in their place nodules can form. They are called atherosclerotic plaques, atheromas. A yellow gruel-like substance is squeezed out of the plaques during cutting. It consists almost entirely of cholesterol esters. The contributing factor for cholesterol deposition is not only a positive balance of cholesterol with the development of lipidosis, but also impaired endothelial barrier permeability in hemodynamically critical areas of the arteries. In these spots, the arterial wall is infiltrated by blood components, including lipoproteins. In the intima, lowdensity lipoproteins (LDL) break up into insoluble lipids, including cholesterol and its esters (CE). Macrophages (MPs) absorb this material, which is foreign to the intimal tissue, via scavenger receptors. Macrophage lysosomal enzymes destroy all components of LDL phagocytic particles except for cholesterol: these cells have no enzymes for any transformations of cholesterol aside from esterification. Cholesterol accumulates in the interstitial intimal substance because of the disintegration of infiltrated LDL and the death of the foam cells formed (the first process is confirmed by light and electron microscopy, specific Sudan III staining by Goldman and is the main one; the formation of foam cells is a secondary event [1]). The accumulation of extracellular lipids in the intima is slow: noticeable lipid deposits are seen after a thirty-year period of life. A significant nucleus of extracellular lipids appears by the mid-thirties. Ultimately, focal lipid deposits, which are foreign for this tissue of the body, form in the intercellular space of the vascular intima. Due to the insolubility, indestructibility of cholesterol, incompleteness of phagocytosis, macrophages, which are overflowed with it, collapse, hydrolytic lysosomal enzymes are released into the extracellular space, oxygen active species enter, and the inflammation develops in the foci. Via the secreted cytokines, including platelet growth factor (PDGF), TNF- $\alpha$, IL-1, fibroblast growth factor (FGF), transforming growth factor- $\beta$ (TGF- $\beta$ ), activated macrophages induce the migration and proliferation of smooth muscle cells (SMC), fibroblasts ( $\mathrm{fb}$ ), which produce elements of the connective tissue and isolate lipid foci. There is a bilateral exchange of cholesterol between the lipid deposits in the wall and the blood plasma. With a positive balance (excessive cholesterol, hyper- 
cholesterolemia (HC)), the influx of cholesterol into the arterial wall prevails and, conversely, with a low cholesterol diet, increased excretion of cholesterol, inhibition of its synthesis, direct removal from the blood, the reverse flow of cholesterol rises.

Dystrophies are pathological processes stemming from a tissue (cell) metabolic imbalance, which leads to structural changes. Therefore, they are considered as one of the types of damage [16]. Due to impaired enzymatic processes, with dystrophies in the cell and/or intercellular substance, there accumulate various metabolic products, which are characterized by quantitative or qualitative change. Among the mechanisms causing the development of typical dystrophic changes, pathologists distinguish between infiltration, decomposition (phanerosis), perverted synthesis and transformation [16]. The mechanism that results in the development of the dystrophy (lipidosis, cholesterolosis), which we are considering, is infiltration. Infiltration is the excessive penetration of metabolic products from the blood and lymph into cells or into extracellular substance with their sequential accumulation, which is associated with a deficiency of enzymatic systems metabolizing these products. Some experimental studies have shown the transition of lipoprotein from the bloodstream to the arterial intima [1, 3] and molecular mechanisms (endocytosis, pinocytosis) of this process. The morphology of this dystrophy demonstrates the accumulation of cholesterol (LDL) in the interstitial substance and cells of intima, often in the middle layer of arteries. It should be noted that atherosclerotic foci of local vascular lesions also manifest signs of stromal vascular dysproteinosis such as mucoid, fibrinoid swelling and hyalinosis, resulting from plasma leakage, necrosis and sclerosis $[1,4,16]$. In accordance with the classification of dystrophies [16] relating to atherosclerosis, we can conclude that it involves the total prevalence of the process of stromal vascular adipose dystrophy of acquired or hereditary origin. The reasons for the development of the dystrophy under consideration primarily include the above-mentioned features of cholesterol metabolism in the human body and the lack of macrophage lysosomal enzymes that could destroy the hydrocarbonic structure of the cholesterol molecule. Being essential for each specific organism (for building membranes, the formation of bile acids, the synthesis of steroid hormones, vitamin D3), cholesterol, if exceeded, can increase the probability of developing atherosclerosis. Disorders of lipid metabolism in the human body are realized through genetic mechanisms. Hyperlipoproteinemias (HLPs) are known to be the most common metabolic disorders: in some populations they are found in 10-25\% of individuals. The dystrophy under consideration results from primary HLP types IIa, IIb, III, IV, V, as well as secondary HLPs in patients with various medical conditions, including diabetes mellitus (DM), hypothyroidism, Cushing's disease, gout, obstructive liver diseases (cholestasis syndrome), nephrotic syndrome, chronic renal failure, alcohol abuse, treatment with corticosteroids, betaadrenergic blocking agents, gestagens, diuretics, and the impact of toxic substances as the most crucial causes. With the listed diseases and conditions, there is an increase in blood LDL and /or VLDL and / or a decrease in HDL. The higher the ratio of LDL + VLDL and HDL concentrations is, the greater the probability of atherosclerotic disease is. A reduced cholesterol efflux from peripheral tissues due to a decreased HDL content and the development of lipidosis are observed in diabetes, obesity, physical inactivity, stress, puberty, menopause, hypertriglyceridemia, cigarette smoking, uremia, treatment with anabolic steroids, beta-adrenergic blocking agents, gestagens, and the use of contraceptives. The most pronounced manifestations of dystrophy are characteristic of HLP types IIA, IIb, III, but its moderate development complicated by atherosclerosis also occurs in types IV and V, which are accompanied by increased blood VLDL. Mutations of LDL receptor genes, apo-B, apo-A1, apo-C3, apo-E genes lead to the development of dystrophy and atherosclerosis. Lipoprotein blood level depends on the combined action of the genes of lipoprotein lipase (LPL), lecithin-cholesterol acyltransferase (LCAT) and other enzymes. These genes have a 
great number of alleles and, as a result, the genetic variation in the concentration of lipoproteins in humans is very broad. Moreover, numerous exogenous effects can change lipoprotein concentration within genetically determined norms. The risk of developing atherosclerosis increases in proportion to an increase in LDL cholesterol; there is a positive correlation between its level and prevalence of coronary heart disease; a quantitative relationship between the level of cholesterol and the incidence of coronary heart disease is observed. The Framingham Heart Study showed that with high blood cholesterol level, coronary heart disease was four times more likely to develop than with low cholesterol. Conversely, cholesterol reduction of $1 \%$ reduced by $2 \%$ the risk of manifestations and the severity of coronary heart disease. The hemodynamic factor, increased blood pressure (BP) contribute to the penetration of cholesterol into the inner wall of blood vessels. To balance the rates of cholesterol influx and efflux in the vascular wall (and stroma of organs), it is crucial to maintain the ratio when about $70 \%$ of plasma cholesterol circulates in LDL and VLDL and $30 \%$ in HDL. For the accumulation of lipoproteins in the vascular intima and stroma of organs, the size and density of these particles are of importance. All in all, the nature of morphogenesis in atherosclerosis and the phase of its progression are determined by the amount of deposited extracellular cholesterol in a particular place in the interstitial tissue of the vascular intima.

The main factors contributing to the development of inflammation in the vascular wall in atherosclerosis are the specific features of the molecular structure of cholesterol: the hydrocarbon skeleton of cyclopentane-perhydrophenanthrene cholesterol cannot be cleaved in the lysosomes of human MPs. These cells break up only CE into free (unesterified) cholesterol and fatty acids. Cells of the human body are able to synthesize a cholesterol ring, but they cannot destroy it. The leading role of the cyclic hydrocarbonic structure of cholesterol, which is insoluble and indestructible by MPs, in the induction of atherosclerosis-related inflammation is confirmed by the fact of the atherogenic action of cholesterol derivatives having its structure. Cholestanol, plant dietary sterols, including $\beta$-sitosterol, campesterol, stigmasterol, have this action. It is noteworthy that plant sterols (PSs) do not cause atherosclerosis in a healthy person, as they are absorbed in minimal amounts, but they show their atherogenicity in patients with familial $\beta$-sitosterolemia, who display increased absorption and deposition of plant sterols in tissues. If among people who receive the so-called "functional nutrition", including esters of plant sterols, for the prevention of atherosclerosis, there are patients with this genetic pathology, they will accelerate the progress of atherosclerosis. Vitamin $\mathrm{D}_{2}$ and vitamin $\mathrm{D}_{3}$, which are derivatives of ergosterol and 7-dihydrocholesterol, respectively, have an atherogenic effect. Furthermore, their large doses can cause necrosis of the muscles of the vascular wall and its calcification. A number of rare genetic disorders of sterol metabolism accompany impaired metabolism of cholesterol and its esters: hepatic lipase deficiency (with accumulation of VLDL and IDLs); a deficiency in lysosomal hydrolase of cholesterol esters with impaired LDL metabolism (Wolman disease); cholesterol ester accumulation disease; cerebrotendinous xanthomatosis; cerebral cholesterolosis; Toichlander and Hand Schüler Christian syndromes.

An important factor in atherogenesis is the crystalline nature of cholesterol: cholesterol esters are liquid crystals; its free form is represented by solid crystals, which are easily detectable in an incised plaque $[1,4,9]$. The precipitation of free cholesterol in the colloid in the form of solid crystals is facilitated by the cleavage of cholesterol esters into free cholesterol and fatty acids, as well as an increase in the ratio of cholesterol/phospholipids (PLs) in lipid foci. The noted properties (insolubility, indestructibility of the molecular structure of cholesterol in MPs and crystalline structure) contribute to the development of chronic productive granulomatous inflam- 
mation - granulomatosis around endogenous foreign bodies. In other words: lipid foci, containing cholesterol and accumulating in the arterial intima, become a trigger of the chronic productive inflammation. The biological meaning of atherosclerotic granulomatous inflammation is the isolation of extracellular lipid foci that are foreign to the tissue of the arterial intima. Among granulomatous diseases, alongside with atherosclerosis, there is such an analogue as gout, which is similar to it in terms of the development mechanism involving the deposits of sodium urate crystals in the tissues as the cause of the inflammatory granulomatous tophi development. Granulomatous inflammation is a local chronic inflammation caused by insoluble or slowly degrading irritants, which is accompanied by focal accumulations of MPs or MPs and epithelioid cells with giant multinucleated cells (GMCs), lymphocytes, granulocytes or without them [2, 12-15]. Macroscopically, granuloma is a dense nodule-like focus of productive inflammationf. Of its three forms developing in the human body, including interstitial, granulomatous and inflammatory hyperplastic (hyperregenerative, polypoid) growths, chronic productive granulomatous inflammation is caused by insoluble or slowly degrading irritants and is realized in the connective tissue system [10-14]. Granulomatous inflammation is intended to "rid" the body of foreign bodies that do not undergo complete degradation by MPs [10-14]. We emphasize once again that with atherosclerosis, lipid foci with quantitatively predominant cholesterol are such foreign bodies for the connective tissue of the intima. Activated MPs are dominant cells in productive granulomatous inflammation, and the main morphological substrate is granuloma (nodule, tubercle by R. Virchow) as the focal accumulation of monocytic-macrophage cells. There distinguish between foreign body granulomas and epithelioid granulomas, which are different by structure. Some foreign body granulomas, however, may contain a small amount of epithelioid cells [20]. D. O. Adams [19] identifies three types of chronic inflammatory macrophage response to a persistent stimulus: 1) the diffuse infiltration of mononuclear phagocytes; 2) the formation of mature macrophage granulomas; 3 ) the formation of epithelioid cell granulomas. The development of granulomas can be associated with the introduction of insoluble or poorly soluble inorganic and organic particles (e. g., silicate, talc, coal, minerals, and oils) into the internal environment of the body. B. Hirsch, W. Johnson classification of granulomas around foreign bodies in the skin [15] notes such endogenous substances as fats, crystals of uric acid salts (UA), keratin, hair, and exogenous ones, including mineral particles and oils, metal salts, tattoos, silicon, silicone, talc, aluminium hydroxide, oils, paraffin, silk, catgut, synthetic fibres, etc. It should be pointed out that the authors refer difficultly soluble fat products to endogenous factors causing the development of inflammatory granulomas. It is also important to note that colloidal solutions of lipids, soaps, lipopolysaccharides can give rise to the formation of granulomas around foreign bodies [15]. Exogenous foreign body granulomas include sutures, caused by starch, talc, barium sulphate, mercury, soot particles, carrigenin, organic and inorganic substances (dust, aerosols, smoke, etc.), drugs, and tattoos. In granulomas, macrophages and their derivatives are concentrated around foreign particles, this material is found in them. According to the definition of W. L. Epstein [20], granulomas around foreign bodies are a nonimmune response of mononuclear phagocytes to an insoluble endogenous or exogenous stimulus. They are similar to "mature macrophage granulomas" by D. O. Adams [19]. In non-immune granulomas formed around foreign bodies, there prevail autoregulation mechanisms due to biologically active substances [20]. According to W. L. Epstein [20], at the first moment, the response to a foreign body is an acute inflammation with the migration of not only mononuclear cells, but also neutrophils. By the end of the day, however, blood monocytes, which rapidly differentiate in MPs (such events are observed at the beginning of the formation of atherosclerotic granulomas), 
prevail in the cell infiltrate. In addition to a compact accumulation of MPs and/or epithelioid cells, the development of granulomas can be accompanied by a number of additional signs: 1) infiltration by other cells - plasma, neutrophilic or eosinophilic granulocytes, lymphocytes; 2) the presence of fibroblasts and the development of sclerosis; 3) the development of destructive changes and necrosis.

As can be seen from the above, in response to the incorporation of lipids (mainly esters and free cholesterol) into the interstitial tissue of the arterial intima, chronic productive (proliferative) granulomatous inflammation develops. Its biological meaning is to isolate these bodies that are foreign to the surrounding tissues. In the emerging focus of inflammation, the response of tissue "cleaners" (macrophages) to an insoluble endogenous stimulus plays a major role. The reason for the development of this pathological process is the failure of the monocytic phagocyte system: ineffective phagocytosis and the inability to destroy cholesterol in macrophage lysosomes are replaced by its isolation. In accordance with the working classification of inflammatory granulomas by academician A. Strukov and O. Kaufman [15], in its essence, the local atherosclerotic process is a chronic productive granulomatous inflammation caused by an endogenous factor [6]. Pathogenetically, atherosclerotic granulomas are non-immune granulomas that form around endogenous foreign bodies - lipid foci in the arterial intima, containing extracellular cholesterol. Histologically, atherosclerotic plaques, atheromas are mature macrophage granulomas of various sizes without giant multinucleated cells or epithelioid cells, with extracellularly located endogenous foreign particles of cholesterol as a colloid, amorphous substance, liquid and solid crystals, with fibrous changes and frequent necrosis in the centre [6].

The reality of the concept of atherogenesis, which we present, is confirmed by the daily practice of pathologists: while incising the artery walls are cut, they reveal single or merging tubercles that have a characteristic structure of granulomas of foreign bodies. In the centre of atherosclerotic granulomas, there are liquid crystals of cholesterol esters, amorphous and crystalline free cholesterol. In addition to the quantitatively predominant cholesterol, the lipid cores of granulomas (or plaques, atheromas) contain other plasma components, triglycerides, fatty acids decomposing under the action of macrophage enzymes, cells and tissues of the intima, PLs, proteins, Ca, soap, fibrin, etc. [1, 4, 9]. The capsule isolates the core, which is insoluble, frequently having a gruel-like appearance, from the surrounding tissues. The typical structure of atherosclerotic granulomas is also confirmed by the presence of a number of cells attracted by macrophage cytokines. including SMC, lymphocytes, fibroblasts, neutrophils, plasma and mast cells (in small quantities), which are localized along the periphery of the deposits. It is noteworthy that for all granulomas around foreign bodies, regardless of their aetiology, the nature of the construction, the involvement of cytokines, and growth factors arethe same [15]. Initially, macrophage activation occurs due to incomplete phagocytosis, as well as due to the granulocyte decomposition products that phagocytose foreign material [15]. Macrophages are the main source of cytokines in atherosclerotic granuloma. Being the main inducer of the inflammatory process, they control all stages of granuloma formation. Macrophages express numerous chemokines, pro-inflammatory cytokines, growth factors, provide for the migration and proliferation of SMC, fb. Lymphocytes play an important role in atherosclerotic granulomas: by isolating macrophage migration inhibitory factor, they contribute to the accumulation of these cells in the foci of inflammation and the formation of granulomas. All components of the formed atherosclerotic granulomas, with the exception of extracellular solid crystals of cholesterol, can be resorbed from them. Connected tissue formed by SMC, which isolates lipid deposits, is also not amenable to resorption.

As an example of granulomas that form around endogenous foreign bodies, pathologists most often use gout. In this disease, granulomatous inflammation develops around the deposits of uric acid salts in the tissues, and manifests itself as a mature 
macrophage granuloma with the presence of giant multinucleated cells. (In the atherosclerotic plaque granulomas, neither giant multinucleated cells nor the markers of the immune mechanism of granuloma formation or epithelioid cells are detected). Apart from sodium urate, the development of inflammatory granulomas is also caused by endogenous crystals of calcium pyrophosphate dihydrate, basic calcium phosphate, monohydrate and dihydrate of calcium oxalate, deposits in homotensic acid in tissues during ochronic disease, etc. "Nodules" in pneumoconiosis have the typical structure of granulomas around foreign bodies. For example, when quartz dust enters the lumen of the alveoli, there is seen MPs release and phagocytosis of dust particles. MPs intensively absorb these particles and turn into so-called "dust" cells. "Dust" cells are formed for the same reason as "foam" cells: phagocytized material that is not destroyed in lysosomes accumulates in them. MPs / dust cells form cell clusters around crystals and at 10-20 day, such clusters develop connective tissue (sclerosis) and mature macrophage granulomas turn first into cell-fibrous granulomas, and then into fibrous ones. The same process occurs in anthracosis, talcosis, berylliosis, aluminosis, other pneumoconioses, as well as in exogenous allergic alveolitis [5].

An important point is that extracellular cholesterol, as a foreign body for tissues, induces productive inflammation and sclerosis not only in the vascular intima, but also in the stromal connective tissue of internal organs. In humans, it causes the development of cirrhosis of the liver, gallbladder cholesterosis with polyps. In experimental animals, it induces inflammation and development of the stromal connective tissue of the lungs, heart, liver, kidneys, spleen, and endocrine organs [17]. Similar changes are found in severe atherosclerosis in humans.

In addition to metabolic, hemodynamic and vascular factors, hormonal, nervous, hereditary and ethnic factors play an important role in atherogenesis. Their effect is mediated primarily through the impact on the metabolism of fats and proteins. Apart from the dietary and lifestyle patterns, racial and ethnic differences in the incidence of lipidosis and antibodies are based on genetic mechanisms: the diversity of antibodies in ethnic groups and populations is determined by the polymorphism of genes that control lipid metabolism and by the frequency of their mutations.

Conclusions. 1. Consideration of atherosclerosis from the perspective of academic definitions shows that the essence of the universal theory of atherosclerosis pathogenesis is a disturbed cholesterol and lipoprotein homestasis with common stromal vascular adipose, adipose protein (or cholesterinosis) dystrophy complicated by the formation of extracellular lipid foci in the interstitial substance of the arterial intima and the development of chronic productive granulomatous inflammation granulomatosis around these endogenous foreign bodies. The foci contain mainly cholesterol, which is insoluble and indestructible by macrophage lysosomal enzymes. 2. Atherosclerotic plaques, atheromas are inflammatory granulomas around endogenous foreign bodies - lipid foci with extracellular cholesterol; histologically, these are mature macrophage granulomas of various diameters, often merging; they have no giant multinucleated cells or epithelioid cells; fibrotic changes, often necrosis, are seen in the centre. By pathogenesis, these are non-immune granulomas. 3 . The formation of granulomas around the cholesterol introduced into the tissue is observed in the experiment, which makes it possible to study the effect of modern anticytokine (biological) and other pharmaceuticals on their development.

Conflict of interests. There is no conflict of interests to disclose for each author.

Reference s

1. Аничков Н. Н. Сосуды // Частная патологическая анатомия. Вып. 2. Сердце и сосуды. - М.; Л.: МЕДГИЗ, 1947. - 350 с.

2. Благодаров В. М., Богомолеиь К. О., Рудницька О. Г., Вербицький В. В. Основи
1. Anichkov N. N. Sosudy// CHastnaya patologicheskaya anatomiya. Vyp. 2. Serdce i sosudy. - M.-L.: MEDGIZ, 1947. - 350 p.

2. Blagodarov V. M., Bogomolec' K. O., Rudnic'ka O. G., Verbic'kij V. V. Osnovi pato- 
патоморфології. В 2-х ч. Ч. 1. Загальна патоморфологія. - К.: ТОВ «Атлант ЮЕмСІ», 2007. - $198 \mathrm{c.}$

3. Горев Н. Н. Экспериментальный атеросклероз и возраст. - М.: Медицина, 1972. $-208 \mathrm{c}$.

4. Давыдовский И. В. Патологическая анатомия и патогенез болезней человека. В 2-х т. - М.: Медгиз, 1958. - Т. 2. - 689 с.

5. Коган Е. А., Корнев Б. М., Попова Е. Н., Фомин В. В. Интерстициальные болезни легких: Практ. руководство / Под ред. Н. А. Мухина. - М.: Литтерра, 2007. $432 \mathrm{c}$.

6. Казимирко В. К., Флегонтова В. В., Гаврилин В. А., Пилькевич Н. Б. Гранулематозные болезни: Уч. пособие для врачей в вопросах и ответах. - Луганск: СПД Резников В. С., 2009. - 420 с.

7. Лопухин Ю. М., Арчаков А. И., Владимиров Ю. А., Коган Э. М. Холестериноз (Холестерин биомембран. Теоретические и клинические аспекты). - М.: Медицина, 1983. - 352 с.

8. Николаев А. Я. Биологическая химия. М.: ООО «Медицинское информационное агенство», 2007. - 568 с.

9. Пальцев М. А., Аничков Н. М. Патологическая анатомия: Учебник. В 2-х т. - М.: Медицина, 2001. - Т. 2. - 736 с.

10. Пауков В. С., Кауфман О. Я. Стадии воспаления. Формы воспаления // Воспаление: Руководство для врачей / Под ред. В. В. Серова, В. С. Паукова. - М.: Медицина, 1995. - С. 76-199.

11. Пауков В. С., Серов В. В. Сущность воспаления, его место в биологии и медицине // Воспаление: Руководство для врачей / Под ред. В. В. Серова, В. С. Паукова. - М.: Медицина, 1995. - С.30-35.

12. Серов В. В. Воспаление // Патологическая анатомия / Под ред. В. В. Серова, М. А. Пальцева. - М.: Медицина, 1998. $146 \mathrm{c}$.

13. Серов В. В., Пауков В. С. Воспаление. М.: Медицина, 1995. - 640 с.

14. Серов В. В., Шехтер А. Б. Соединительная ткань (функциональная морфология и общая патология). - М.: Медицина, 1981. -312 c.

15. Струков А. И., Кауфман О. Я. Гранулематозное воспаление и гранулематозные болезни. - М: Медицина, 1989. - 179 с.

16. Струков А. I., Сєров В. В. Патологічна анатомія. - Х.: Факт, 1999. - 864 с.

17. Хмельницкий О. К., Ступина А. С. Функциональная морфология эндокринной системы при атеросклерозе и старении. - М.: Медицина, 1989. - 248 с. morfologiï. V 2-h ch. CH. 1. Zagal'na patomorfologiya. - K.: TOV «Atlant YuEmSI», 2007. - 198 p.

3. Gorev N. N. Eksperimental'nyj ateroskleroz i vozrast. - M.: Medicina, 1972. - 208 p.

4. Davydovskij I. V. Patologicheskaya anatomiya i patogenez boleznej cheloveka. V 2-h t. - M.: Medgiz, 1958. - T. 2. - 689 p.

5. Kogan E. A., Kornev B. M., Popova E. N., Fomin $V$. V. Intersticial'nye bolezni legkih: Prakt. rukovodstvo / Pod red. N. A. Muhina. - M.: Litterra, 2007. -432 p.

6. Kazymyrko V. K., Flegontova V. V., Gavrilin V. A., Pil'kevich N. B. Granulematoznye bolezni: Uch. posobie dlya vrachej v voprosah i otvetah. - Lugansk: SPD Reznikov V. S., 2009. - 420 p.

7. Lopuhin Yu. M., Archakov A. I., Vladimirov Yu. A., Kogan E. M. Holesterinoz (Holesterin biomembran. Teoreticheskie i klinicheskie aspekty). - M.: Medicina, 1983.$352 \mathrm{p}$.

8. Nikolaev A. Ya. Biologicheskaya himiya.M.: OOO «Medicinskoe informacionnoe agenstvo», 2007. - $568 \mathrm{p}$.

9. Pal'cev M. A., Anichkov N. M. Patologicheskaya anatomiya: Uchebnik. V 2-h t. - M.: Medicina, 2001. - T. 2. -736 p.

10. Paukov V. S., Kaufman O. Ya. Stadii vospaleniya. Formy vospaleniya // Vospalenie: Rukovodstvo dlya vrachej / Pod red. V. V. Serova, V. S. Paukova. - M.: Medicina, 1995. - p. 176-199.

11. Paukov V. S., Serov V. V. Sushchnost' vospaleniya, ego mesto $\mathrm{v}$ biologii i medicine // Vospalenie: Rukovodstvo dlya vrachej / Pod red. V. V. Serova, V. S. Paukova. - M.: Medicina, 1995. -p. p.30-35.

12. Serov V. V. Vospalenie // Patologicheskaya anatomiya / Pod red. V. V. Serova, M. A. Pal'ceva. - M.: Medicina, 1998. $146 \mathrm{p}$.

13. Serov V. V., Paukov V. S. Vospalenie. - M.: Medicina, 1995. - 640 p.

14. Serov V. V., SHekhter A. B. Soedinitel'naya tkan' (funkcional'naya morfologiya i obshchaya patologiya). - M.: Medicina, 1981. -312 p.

15. Strukov A. I., Kaufman O. Ya. Granulematoznoe vospalenie i granulematoznye bolezni. - M: Medicina, 1989. - 179 p.

16. Strukov A. I., Scrov V. V. Patologichna anatomiya. - H.: Fakt, 1999. - 864 p.

17. Hmel'nickij O. K., Stupina A. S. Funkcional'naya morfologiya endokrinnoj sistemy pri ateroskleroze i starenii. - M.: Medicina, 1989. - 248 p. 
18. Шехтер А. Б., Серов В. В. Воспаление и регенерація // Воспаление: Руководство для врачей / Под ред. В. В. Серова, В. С. Паукова. - М.: Медицина, 1995. $200 \mathrm{c}$.

19. Adams D. O. The Biology of the granuloma // Pathology of granuloma/ Ed. H. Joachim. - New York, 1983. - P. 1-20.

20. Epstein W. L. Foreing body granulomas // Basic and clinical aspects granulomatous diseases / Ed. D. L. Boros, T. Yochida. - New York, 1980. - P. 133-148.

\section{УНІВЕРСАЛЬНА ТЕОРІЯ ПАТОГЕНЕЗУ АТЕРОСКЛЕРОЗУ}

В. К. Казимирко, Л. М. Іваніцька,

T. С. Сілантьєва, В. В. Кутовий (Київ)

У статті показано, що атеросклероз (Ат), як наслідок порушення гомеостазу холестерину в організмі, розвитку системної стромально-судинної ліпідно-білкової дистрофії (або ліпідозу, або холестеринозу), ускладнюється позаклітинними відкладаннями в проміжній тканині внутрішньої оболонки артерій і аорти вогнищ ліпідів 3 превалюючим у них холестерином (XC), якіє чужорідними (сторонніми) для цієї тканини тілами, що індукують розвиток в ній хронічного продуктивного гранулематозного запалення - гранулематозу навколо ендогенних чужорідних тіл. Умовою відкладання холестерину є його позитивний баланс в організмі, підвищена проникність ендотелію в гемодинамічно вразливих ділянках артерій, стінку яких інфільтрують компоненти крові, зокрема ліпідопротеїни; відсутність у лізосомах клітин гідролітичних ферментів, які могли б зруйнувати стероїдне ядро молекули ХС. Перевищення кількості ХC, необхідного для кожного індивідуального організму (для побудови мембран, утворення жовчних кислот, синтезу стероїдних гормонів, вітаміну $\mathrm{D}_{3}$ ), збільшує ймовірність розвитку атеросклерозу. В порушенні ліпідно-білкового обміну в організмі людини беруть участь генетичні механізми. Найпоширенішим порушенням $\epsilon$ гіперліпопротеїнемія (ГЛП). Зазначена дистрофія є наслідком первинних ГЛП IIa, IIb, III, IV, V типів, вторинних ГЛП у хворих з різними захворюваннями і станами, під час яких має місце збільшення у крові вмісту ЛПНЩ i/або ЛПДНЩ i/або зниження вмісту ЛПВЩ. Зниження дренажу ХС з периферичних тканин в результаті зменшення кількості ЛПВЩ $\mathrm{i}$ розвиток ліпідозу спостерігаються при цукровому діабеті, ожирінні, гіподинамії, стресі, в пубертатному періоді, під час менопаузи, при гіпертригліцеридемії, курінні цигарок, уремії, лікуванні анаболічними стероїдами, $\beta$-адреноблокаторами, гестагенами, при застосуванні протизаплідних засобів. Найбільш виражені прояви дистрофії характерні для ГЛП IIa, IIb, III типів, їі помірний розвиток з ускладненням у вигляді атеросклерозу має місце також при IV i V типах, які супроводжуються підвищенням рівня ЛПДНЩ у крові. До розвитку стромально-судинної дистрофії і атеросклерозу призводять мутації генів рецепторів до ЛПНЩ та генів апопротеїнів. Порушенням обміну холестерину та його ефірів супроводжується ряд рідкісних генетичних порушень метаболізму стеринів: дефіцит печінкової ліпази (з накопиченням ЛПДНЩ і ЛППП); недостатність лізосомної гідролази ефірів ХС з порушенням метаболізму ЛПНЩ (хвороба Вольмана); хвороба накопичення ефірів ХC; церебро-сухожильний ксантоматоз; церебральний холестериноз; синдроми Тойчлендера і Хенда - Шюлера - Крісчена. Основним фактором розвитку запалення у внутрішній оболонці артерій і аорти при атеросклерозі є непорушна в лізосомах макрофагів циклічна вуглеводнева молекулярна структура ХС. Провідна роль в індукуванні атеросклерозного запалення нерозчинної і неруйнівної макрофагами циклічної вуглеводневої структури ХC підтверджується фактом атерогенної дії похідних ХC, які мають його структуру. Важливим фактором запального морфогенезу є ліпопротеїновий дисколлоїдоз в інтимі артерій, фізико-хімічний метаморфоз холестерину. Колоїдний розчин, тверді кристали вільного ХC і рідкі кристали ефірів ХC спричиняють флогогенний і склерогенний ефекти в проміжній тканині інтими артерій.

Ключові слова: атеросклероз; стромально-судинна ліпідно-білкова дистрофія; холестерин; гранульоматоз навколо ендогенних чужорідних тіл. 


\title{
УНИВЕРСАЛЬНАЯ ТЕОРИЯ ПАТОГЕНЕЗА АТЕРОСКЛЕРОЗА
}

\author{
В. К. Казимирко, Л. Н. Иваниикая, \\ T. С. Силантьева, В. В. Кутовой (Киев)
}

В статье показано, что атеросклероз (Ат), как следствие нарушения гомеостазиса холестерина в организме развития системной стромально-сосудистой липидно-белковой дистрофии (или липидоза, или холестериноза), осложняется внеклеточными отложениями в промежуточной ткани внутренней оболочки артерий и аорты очагов липидов с превалирующим в них холестерином (ХC), которые являются чужеродными (внешними) для этой ткани телами, индуцирующими развитие в ней хронического продуктивного гранулематозного воспаления - гранулематоза вокруг эндогенных инородных тел. Условием отложения холестерина является его положительный баланс в организме, повышенная проницаемость эндотелия в гемодинамически уязвимых участках артерий, стенку которых инфильтрируют компоненты крови, в частности липопротеины; отсутствие в лизосомах клеток гидролитических ферментов, которые могли бы разрушить стероидное ядро молекулы ХС. Превышение количества ХC, необходимого для каждого индивидуального организма (для построения мембран, образования жёлчных кислот, синтеза стероидных гормонов, витамина $\mathrm{D}_{3}$ ), увеличивает вероятность развития атеросклероза. В нарушении липидно-белкового обмена в организме человека участвуют генетические механизмы. Самым распространённым нарушением является гиперлипопротеинемия (ГЛП). Указанная дистрофия является следствием первичных ГЛП IIa, IIb, III, IV, V типов, вторичных ГЛП у больных с различными заболеваниями и состояниями, при которых отмечается увеличение в крови содержания ЛПНП и/или ЛПОНП и/или снижение содержания ЛПВП. Снижение дренажа ХС из периферических тканей в результате уменьшения количества ЛПВП и развитие липидоза наблюдаются при сахарном диабете, ожирении, гиподинамии, стрессе, в пубертатном периоде, во время менопаузы, при гипертриглицеридемии, курении сигарет, уремии, лечении анаболическими стероидами, $\beta$-адреноблокаторами, гестагенами, при применении противозачаточных средств. Наиболее выраженные проявления дистрофии характерны для ГЛП IIa, IIb, III типов, её умеренное развитие с осложнением в виде атеросклероза имеет место также при IV и V типах, которые сопровождаются повышением уровня ЛПОНП в крови. К развитию стромально-сосудистой дистрофии и атеросклероза приводят мутации генов рецепторов ЛПНП и генов апопротеинов. Нарушением обмена холестерина и его эфиров сопровождается ряд редких генетических нарушений метаболизма стеринов: дефицит печёночной липазы (с накоплением ЛПОНП и ЛППП); недостаточность лизосомной гидролазы эфиров $\mathrm{XC}$ с нарушением метаболизма ЛПНП (болезнь Вольмана), болезнь накопления эфиров ХС; церебро-сухожильный ксантоматоз; церебральный холестериноз; синдромы Тойчлендера и Хенда - Шюллера - Крисчена. Основным фактором развития воспаления во внутренней оболочке артерий и аорты при атеросклерозе является неразрушимая в лизосомах макрофагов циклическая молекулярная структура ХС. Ведущая роль в индукции атеросклеротического воспаления нерастворимой и неразрушаемой макрофагами циклической углеводородной структуры ХC подтверждается фактом атерогенного действия производных ХC, которые имеют его структуру. Важным фактором воспалительного морфогенеза является липопротеиновый дисколлоидоз в интиме артерий, физико-химический метаморфоз холестерина. Коллоидный раствор, твёрдые кристаллы свободного ХС и жидкие кристаллы эфиров ХС вызывают флогогенный и склерогенный эффект в промежуточной ткани интимы артерий.

Ключевые слова: атеросклероз; стромально-сосудистая липидно-белковая дистрофия; холестерин; гранулематоз вокруг эндогенных инородных тел. 